\title{
ظاهرة التدخين وأبعادها الدلالية \\ في شعر نزار قباني
}

\section{إعداد \\ د// عامر محمود عحد ربيع}

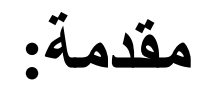

في وقت يحذر العالم كله ويمنع التدخين ويرى فيه موتاً للإنسان

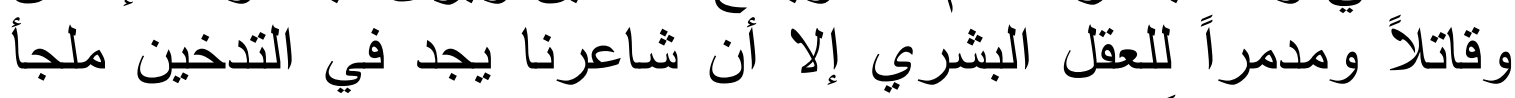

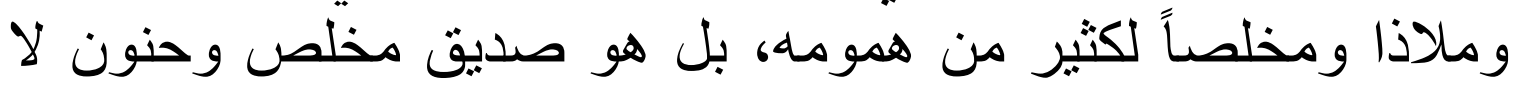

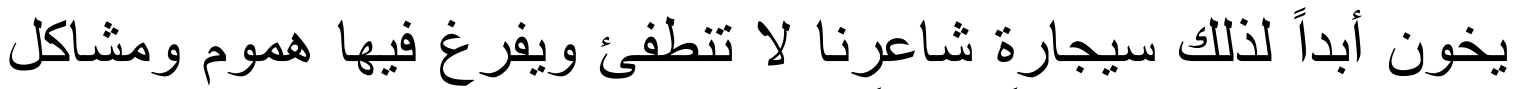

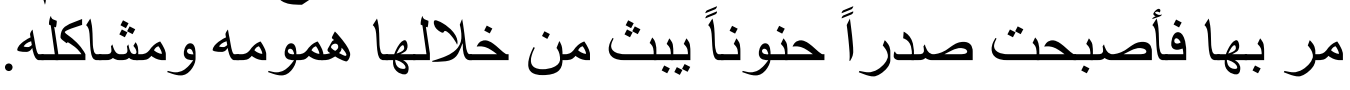

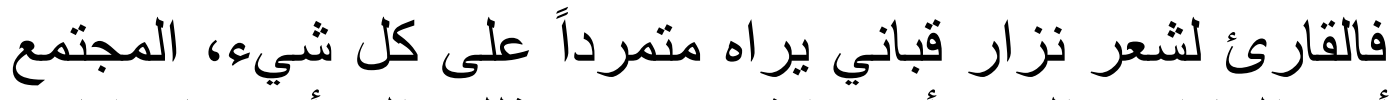

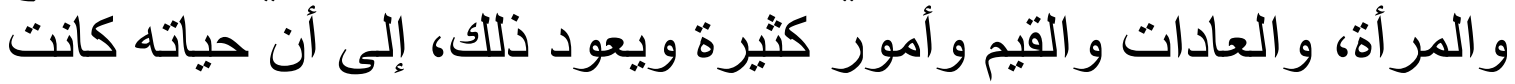

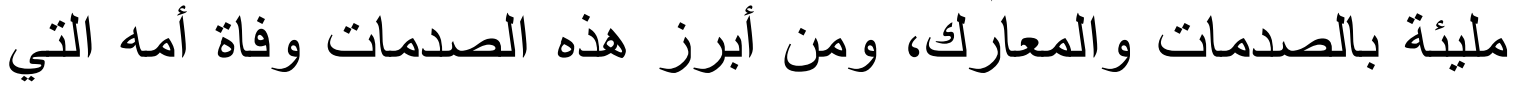

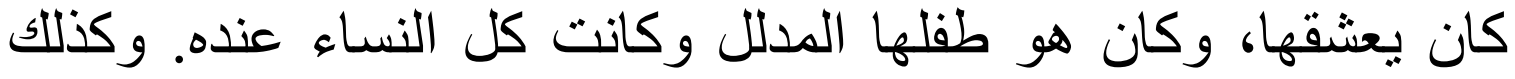

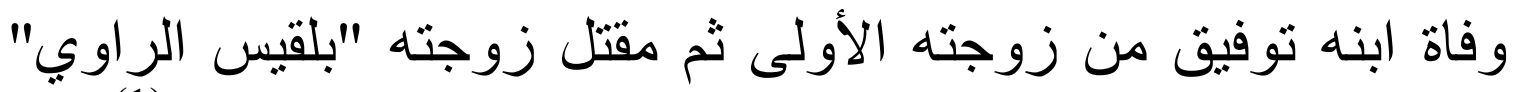

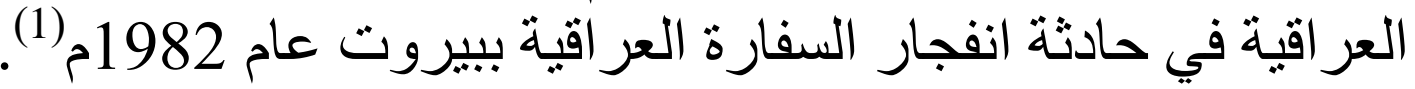

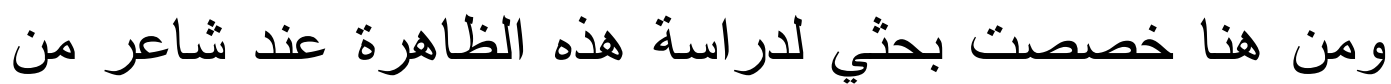

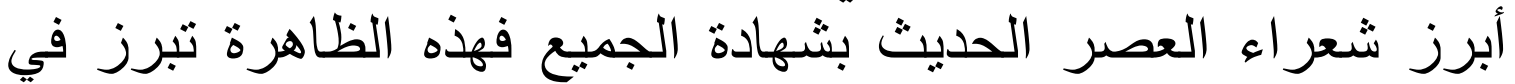
أغلب قصائد وشعر نزار قباني وتسوغ في إطار لهذا البحث أن النقاد

\footnotetext{
) نزار قباني الأعمال الكاملة / يوسف أبو الحجاج الأقصري، دار الحرم للتراث 45 سوق الكتاب الجديد دالعتبه، 1)

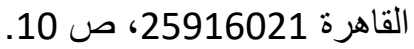


و الباحثين لم يلتفتوا إلى هذه الظاهرة مطلقاً على الرغم من كثرة

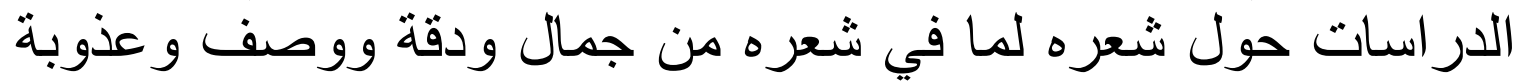

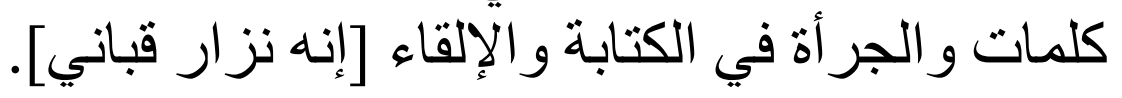




\section{تعريف بالشاعر:}

(ولا نزار في بيت من بيوت دمثق القديمة(2) (مئننة الشحم) بحي الثاغور بالقرب من سوق الحميدية والمسجد الأموي، وهو دون مسلم

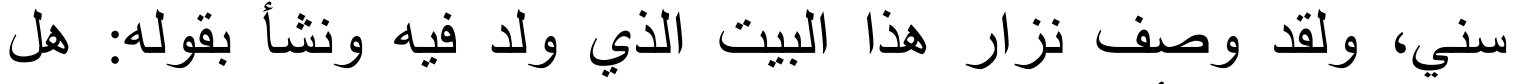

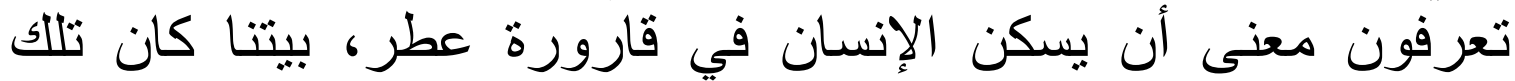

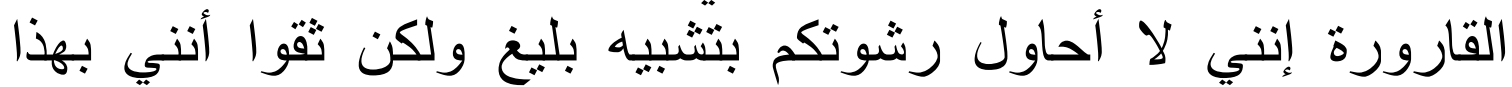

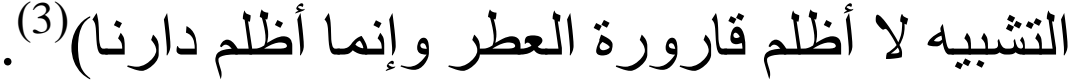

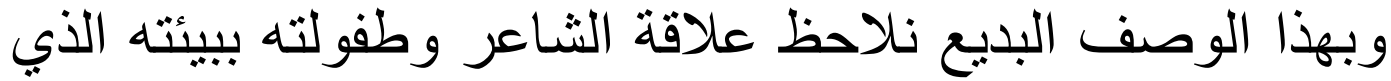

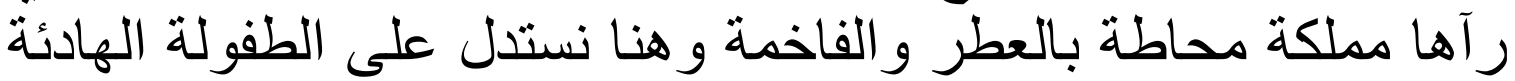

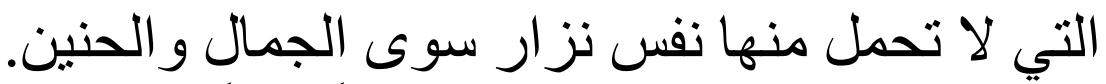

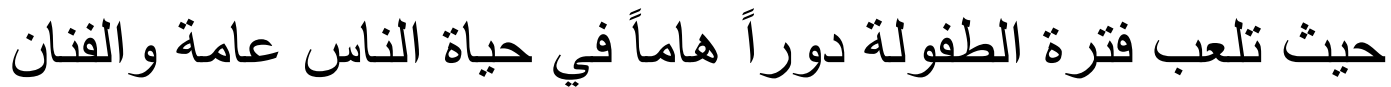

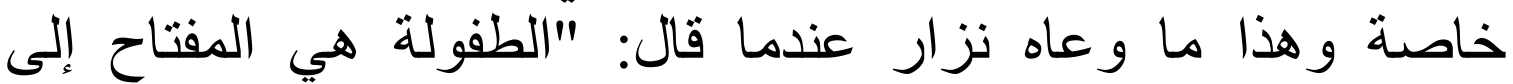

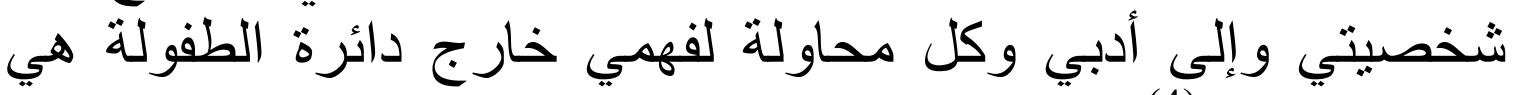

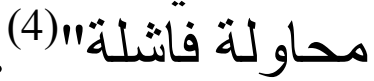
بدأ نزار يكتب الثعر و عمره 16 سنة، وأصدار أول أول دواوينه

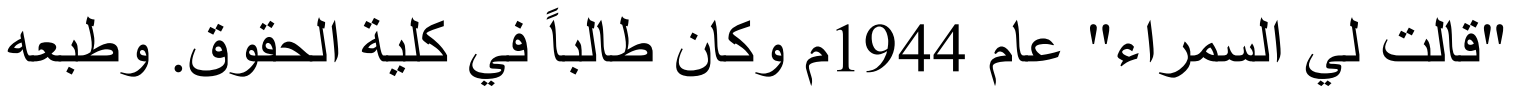
على نفقته الخاصة. وله عدد كبير من دواوين الثنعر تصل إله إلى 35

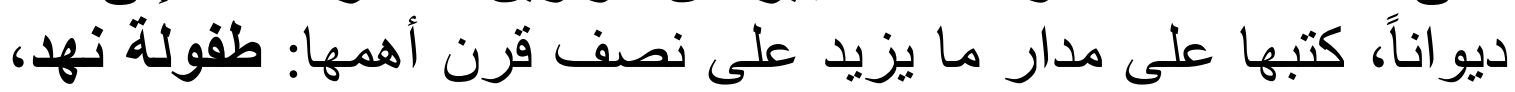
الرسم بالكلمات، قصائد، ساميا، أنت لئ عي.

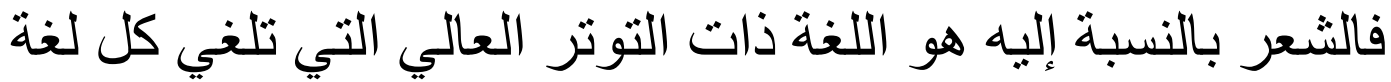

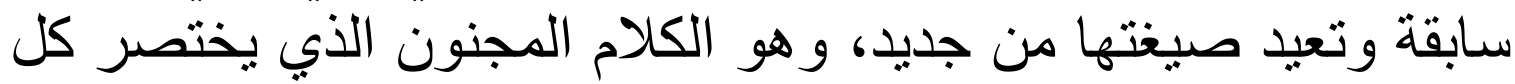

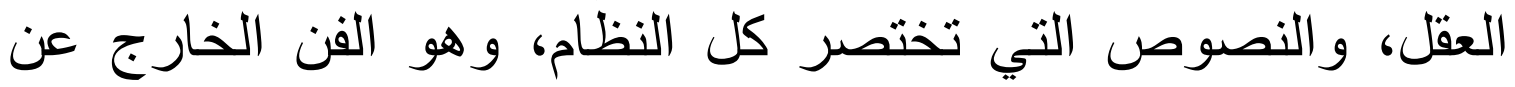

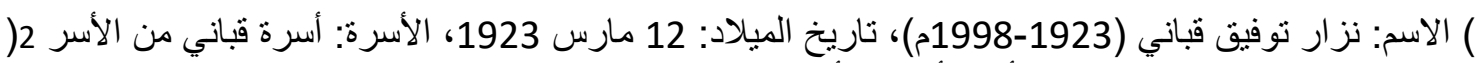

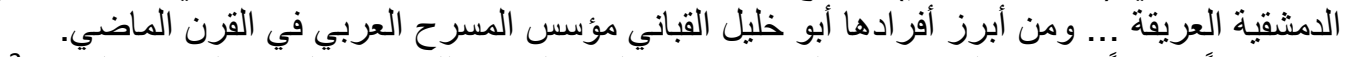

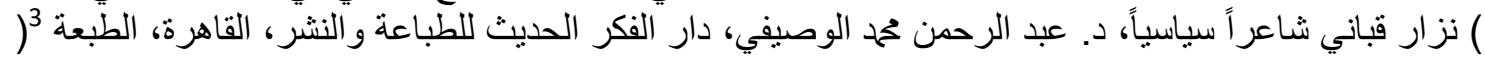

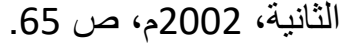

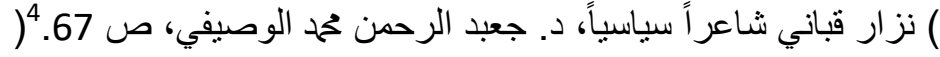


القانون ويعكس قمة العدالة، و هو حفلة الألعاب النارية وتشمل الماء

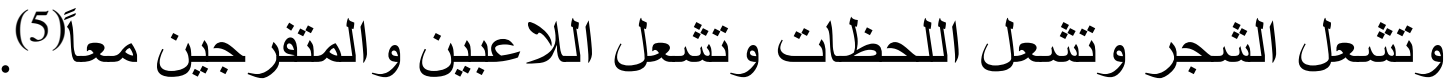

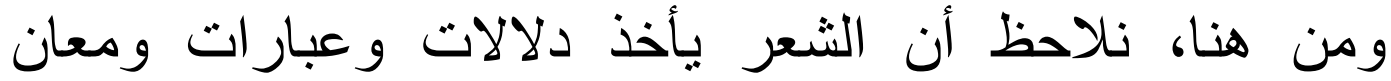

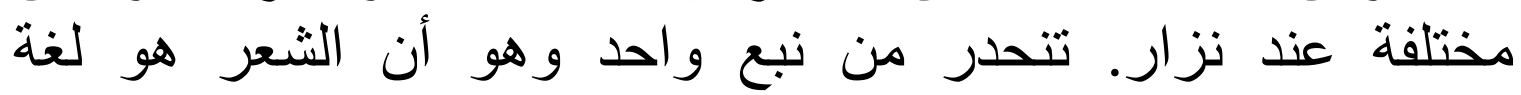
التو اصل. وهو الفرح وهو النار وهو القوة و السلام و الموت وهو وهو

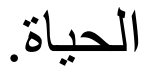

وسنحاول في هذا البحث دراسة تصل لشعرية تعبر عن ظاهرة التدخين ودلالتها النفسية عند شاعرنا.

) الثاعران حيدر محمود ونزار قباني، دراسات نقدية. أ. د. محم أحمد المجالي، منشورات أمانة عمان 2008. 5 ( . $242-241$ ص 240 
صديقتي وسجائري:

واصل تدخينكَ يغريني رجلّ في لحظة تلاخين

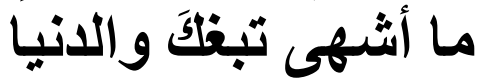

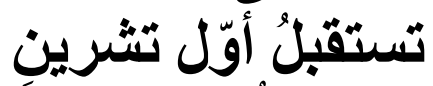

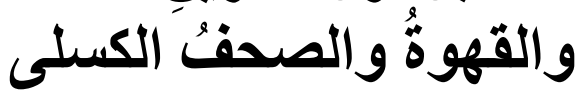
ورؤئً وحطامُ فناجين

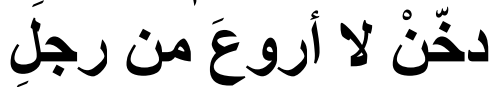
يقنى في الركن ويُقنتيني

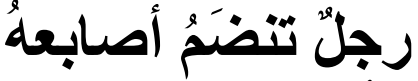

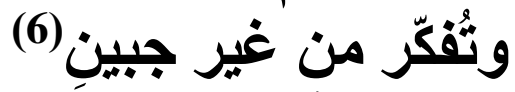

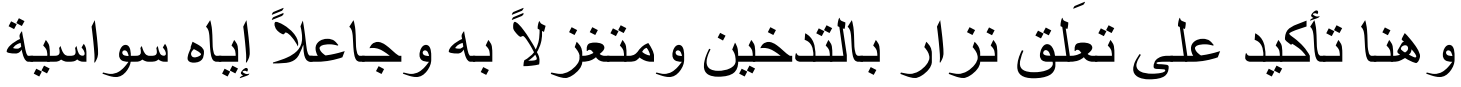

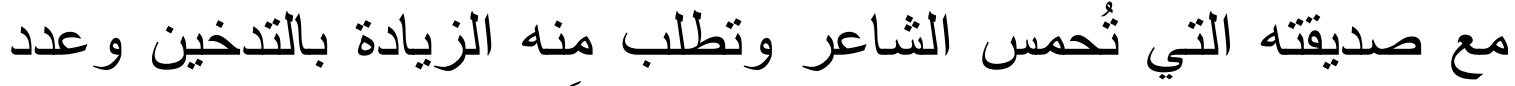

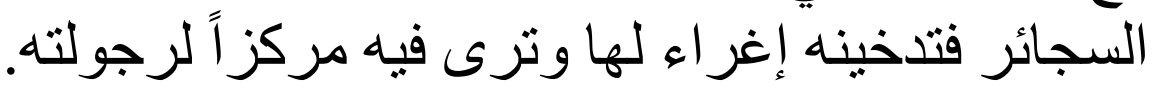

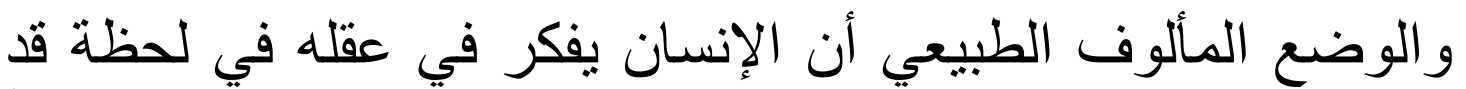

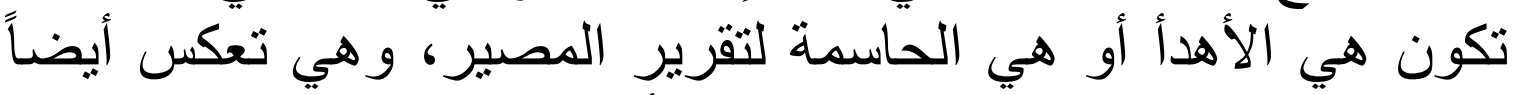

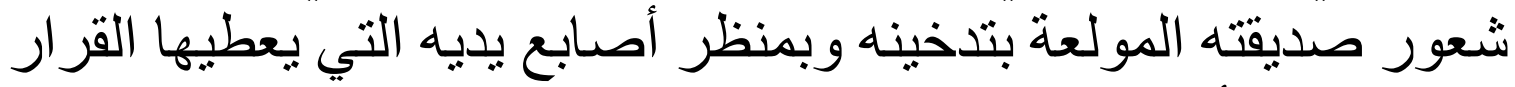

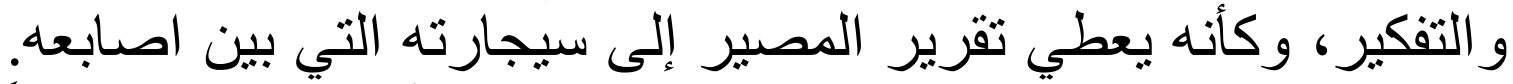

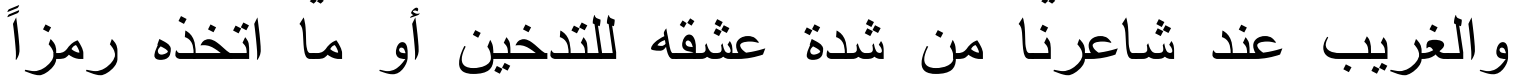

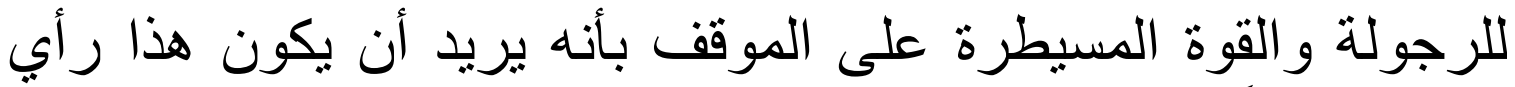

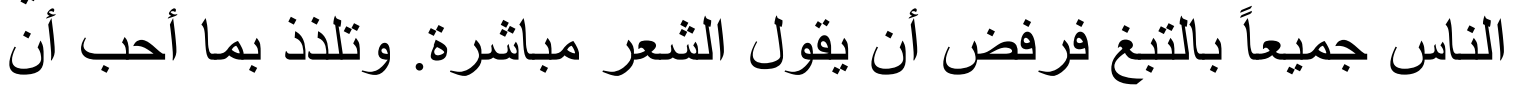

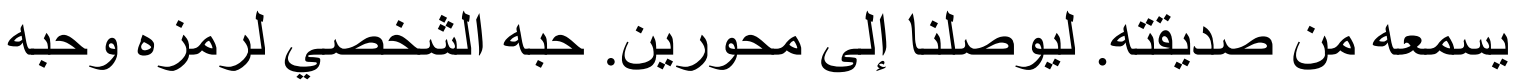
بسماع الغزل بسيجارته من الصديقة.

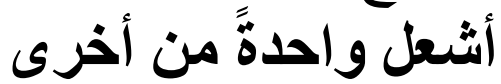

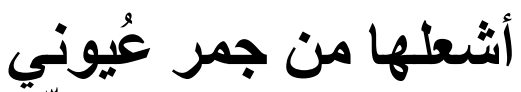
ورمادك ضمه على كنّي

) الأعمال الكاملة لنزار قباني، ص 143.6 
تير انثَ ليست ثوئذيني)

وفي نفس القصيدة (صديقتي وسجائري) المقطع الثاني. نلاحظ

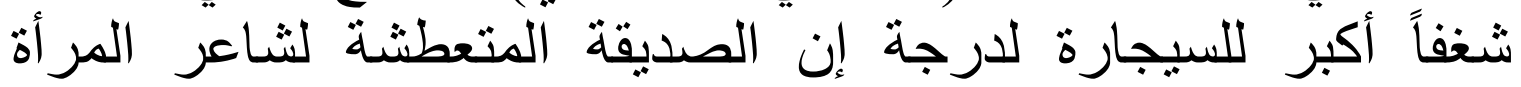

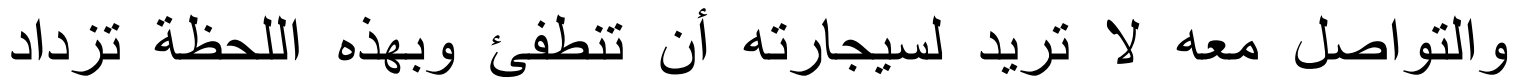
العواطف والإعجاب وتشعل النار في عيون معثوقة نزار لتأمره أن يشعل سيجارته من جمر عيونها. و لا تكتفي بذللك فهي تريد أن تحيط

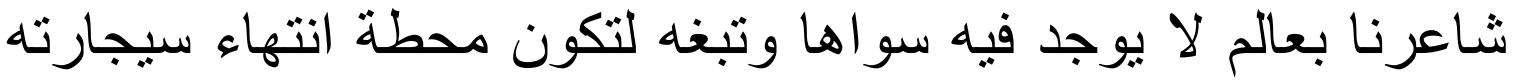
و هي محطة حنين الثاعر وهي كف المعثوقة. فنيران العثق لا تحرق صاحبها. ورنا يتضح جلياً لهو الثاعر. وقد رأى فرويد أن اللهو (ويعني فرويد باللهو ما هو موروث وموجود في النفس منذ الو لادة

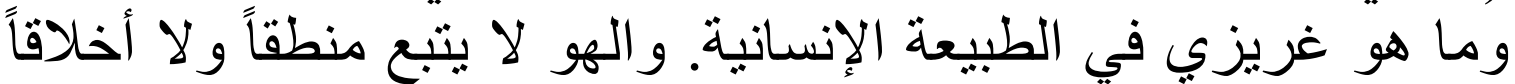
و لا بكثرث بالو اقع. إنه بعمل بطريقة من شأنها تفريغ التوتر مباثرة و عودة الكائن الحي إلى مستوى ثثابت ومنخفض ومريح مريح من الطاقة. ويسمى مبدأ خفض التوثر الذي بعدى الذه اللهو وفقه (مبدأ اللذة))(8). ثداخثن

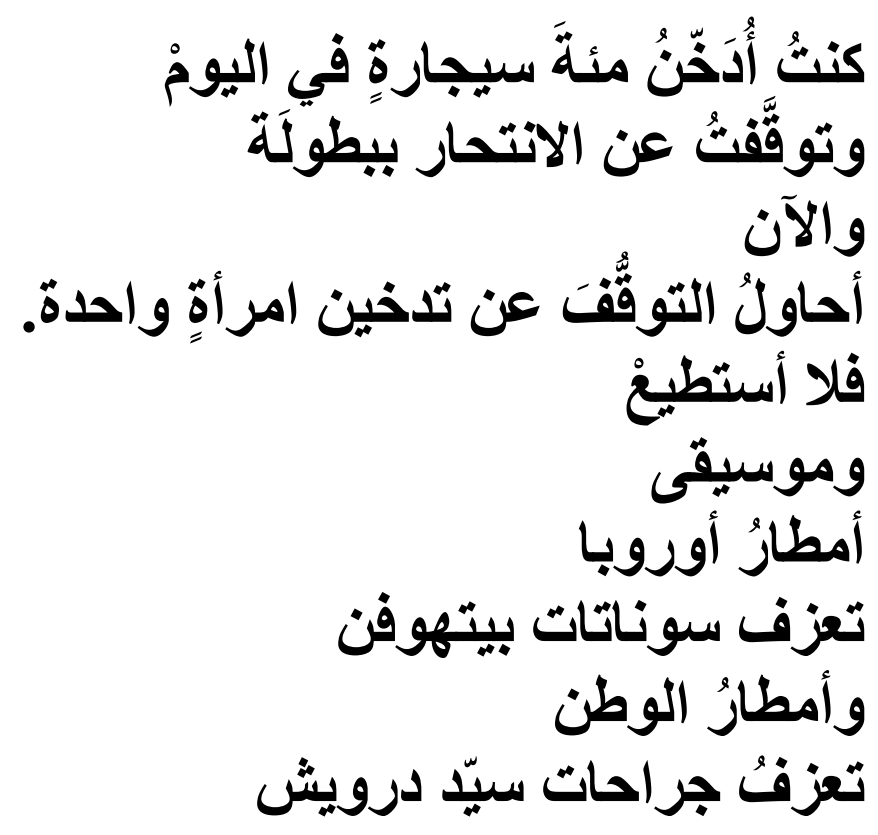

) العمال الكاملة لنزار قباني، يوسف أبو الحاج الأقصري. ص 143.

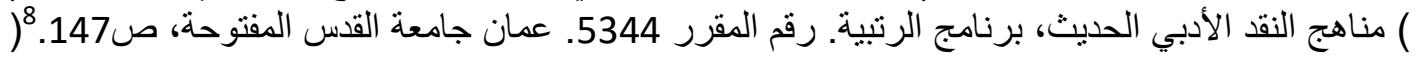




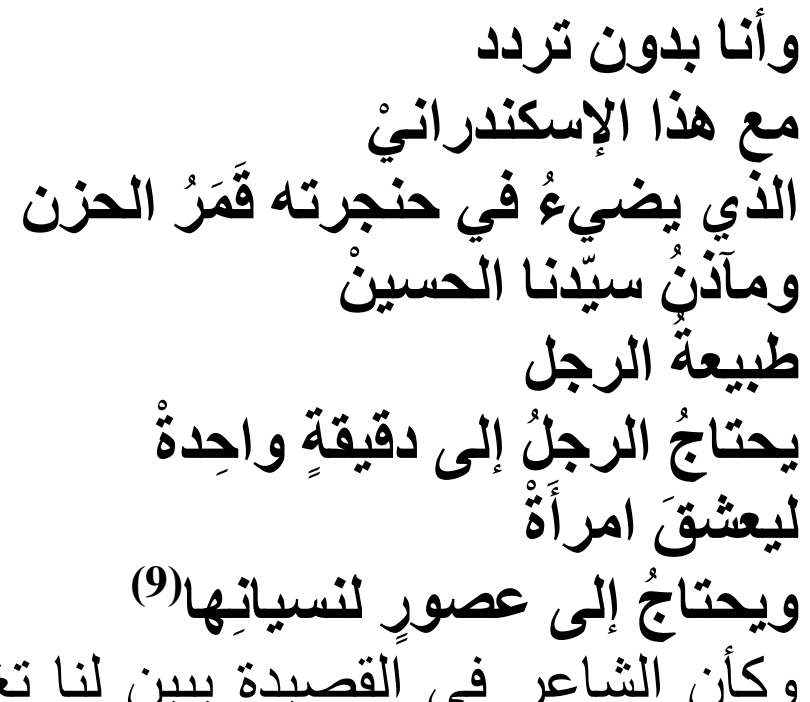

وكأن الثاعر في الِّليدة يبين لنا تغيير في فكره و عاداته ومعتقداته

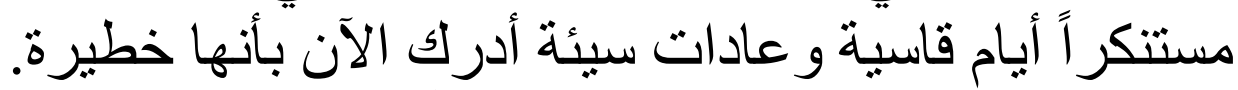

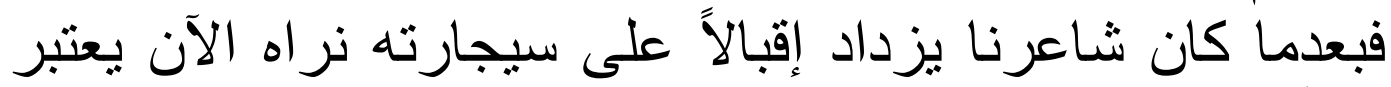

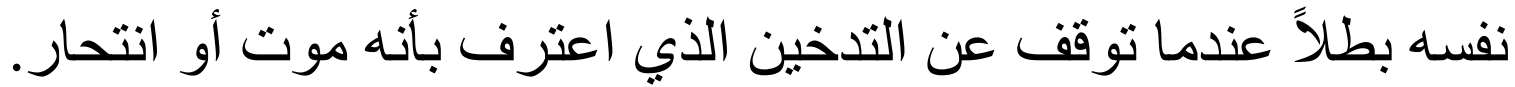

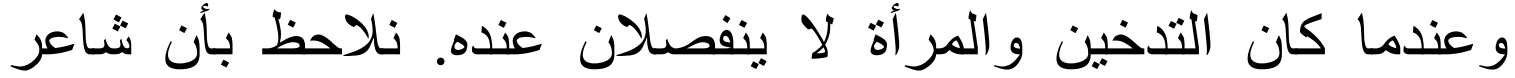

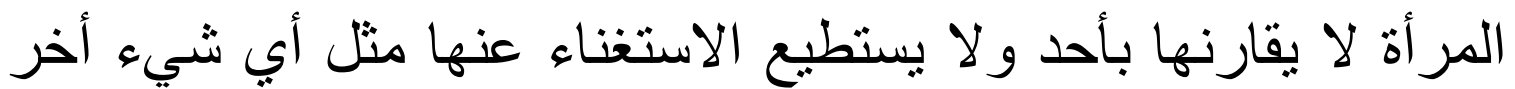

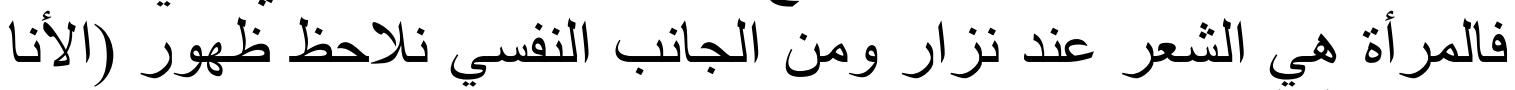
الأعلى)(10)، في هذه القهر القصيدة.

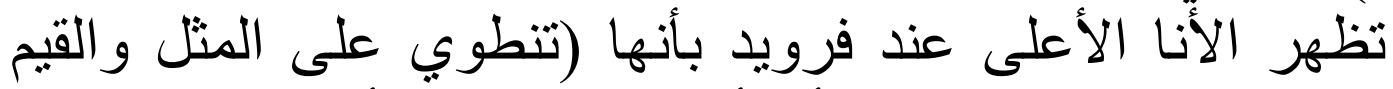

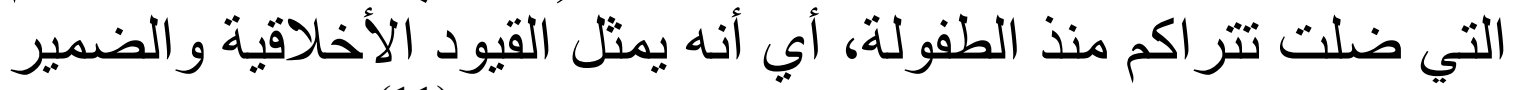

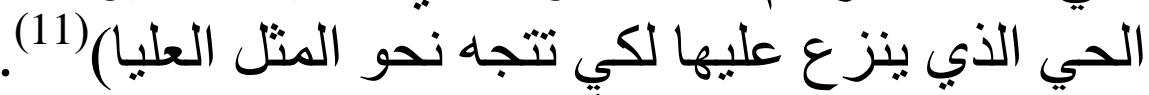

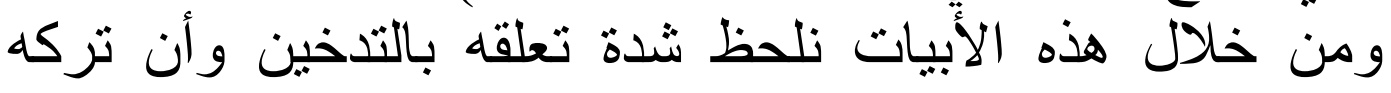

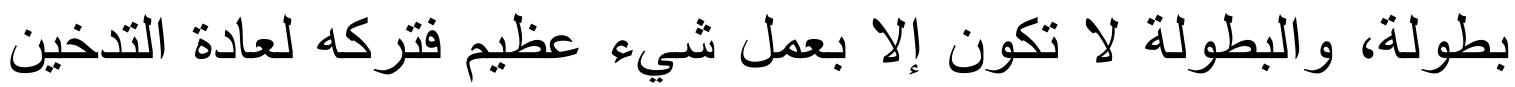

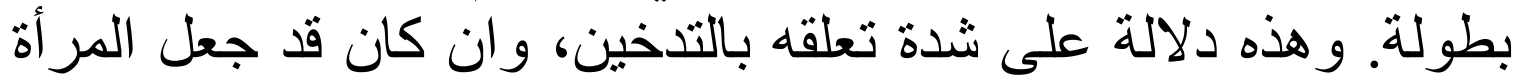

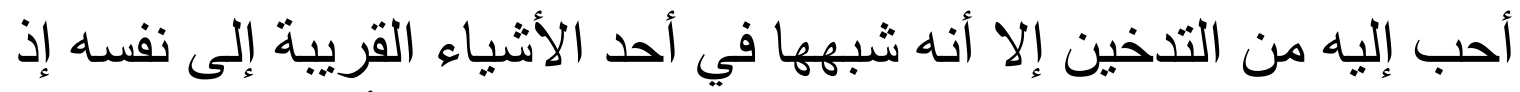
جعلها كالسيجارة بل هي السيجارة نفسها "تدخين المر أنه".

) الأعمال الكاملة لنزار قباني ويوسف أبو الحجاج الأقصري ص 376،

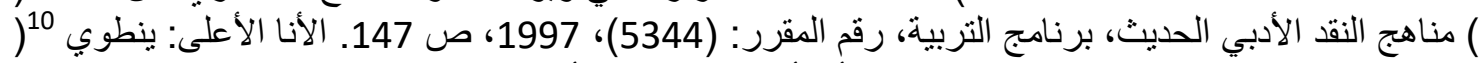

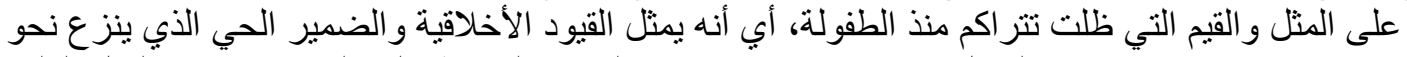

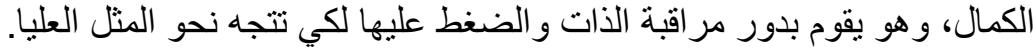

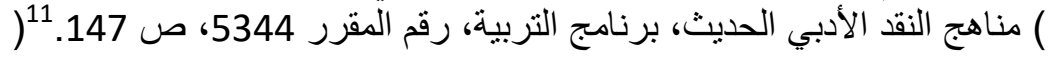




\section{المُدَخِنة الجميلة}

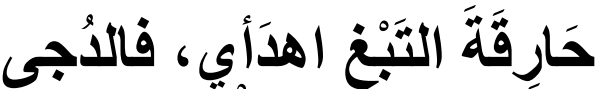

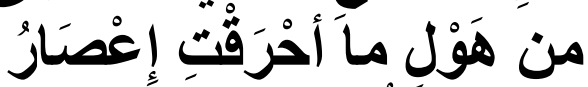

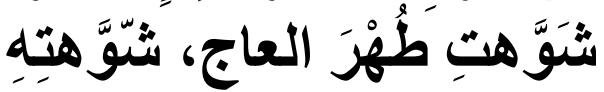

وغابَ في الضَبَاب إسوَارُ

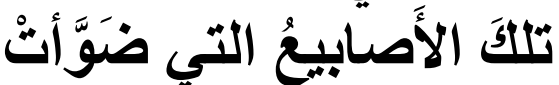

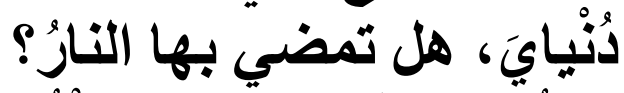

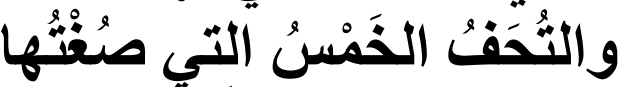

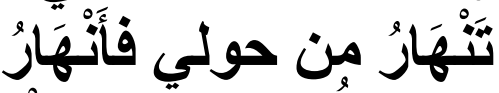

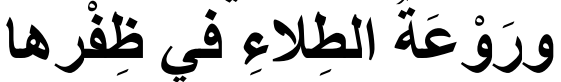
تمضي. فما للفجر آثارُ

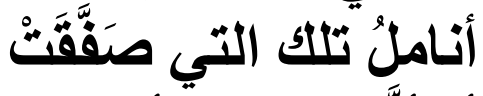

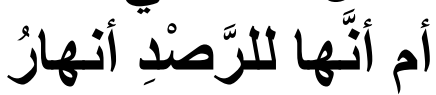

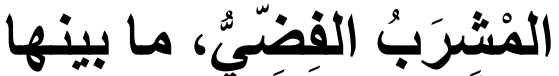

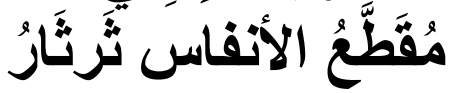

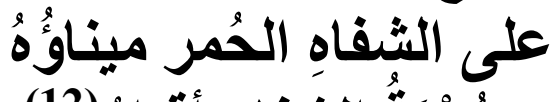

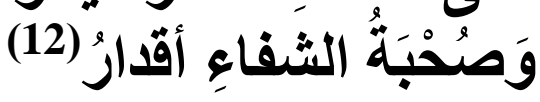

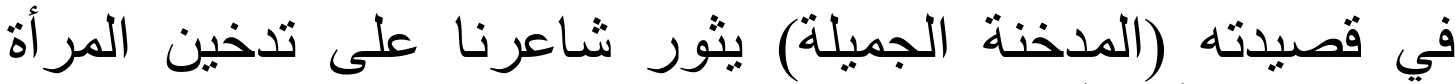

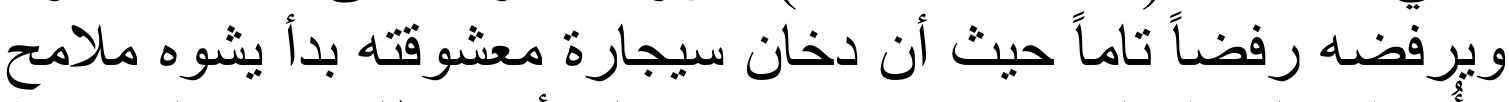

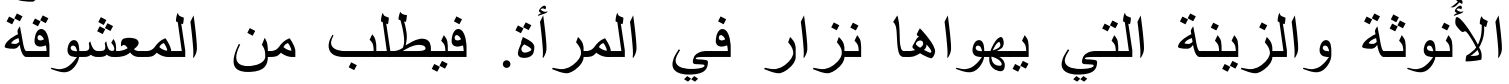

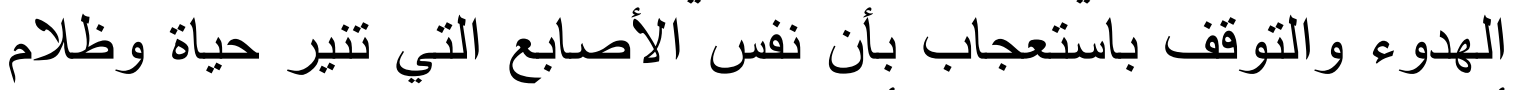

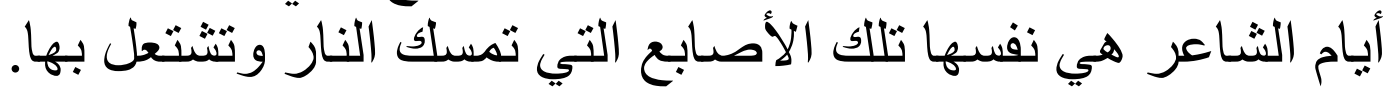

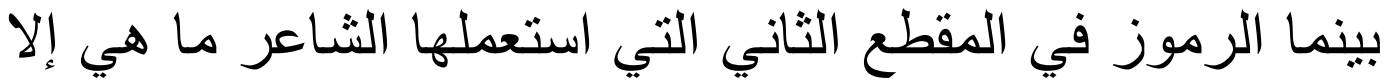

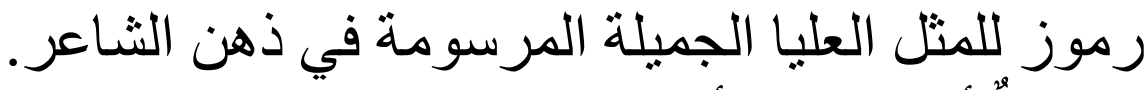

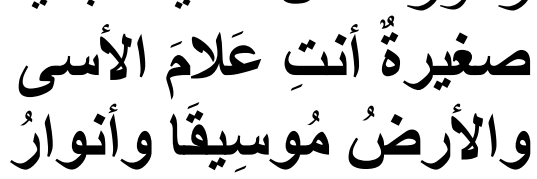

) الأعمال الكاملة لنزار قباني، ص 423.12 


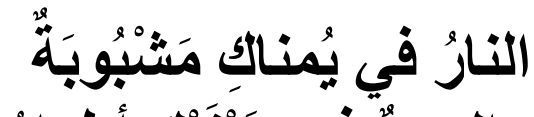

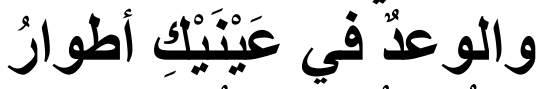

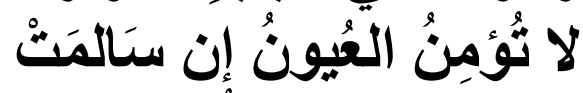

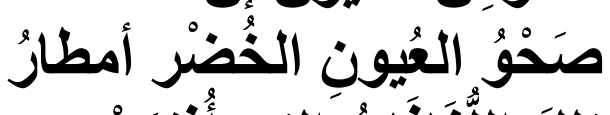

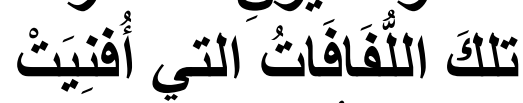

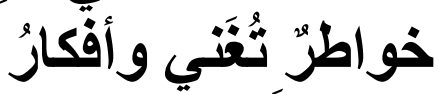

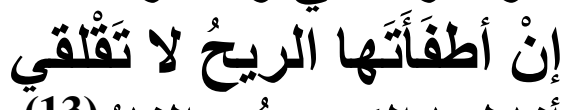

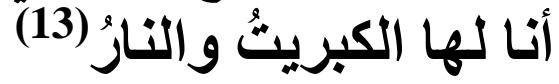

قد يرى بعضهم تناقضاً و اضحاً في هذا المقطع وكأن شـاعرنا لا

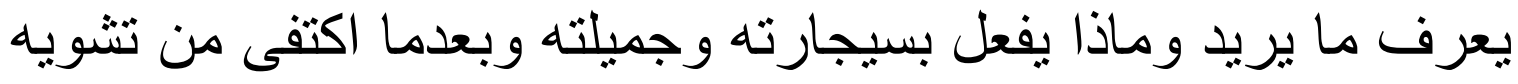

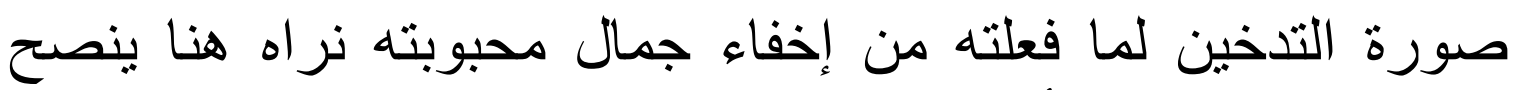

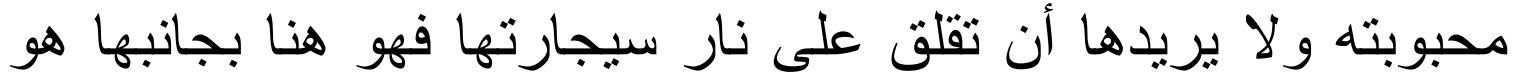

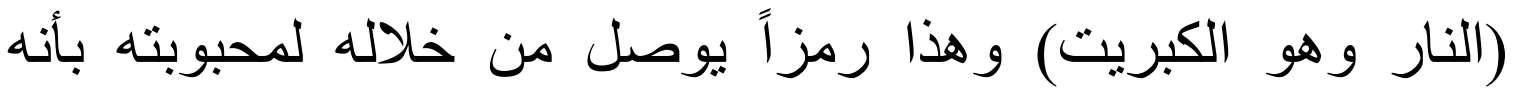

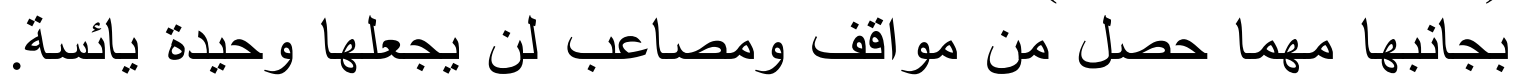

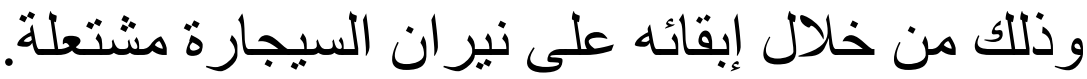

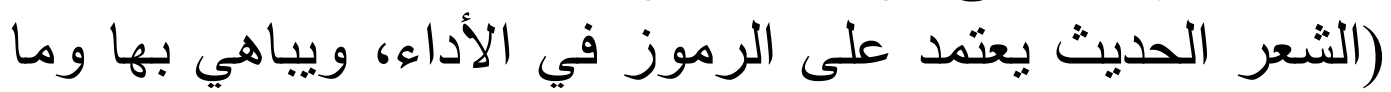

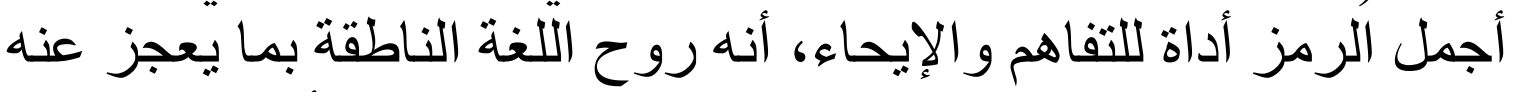

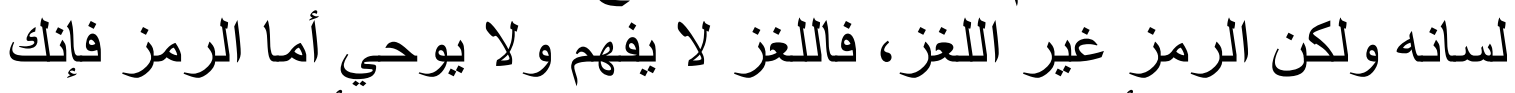

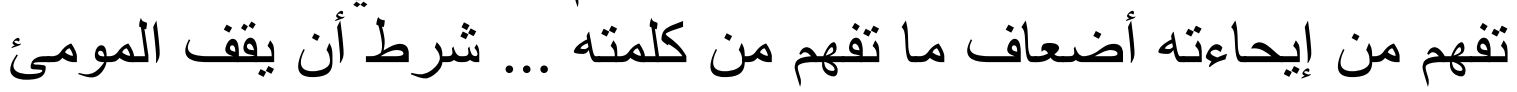

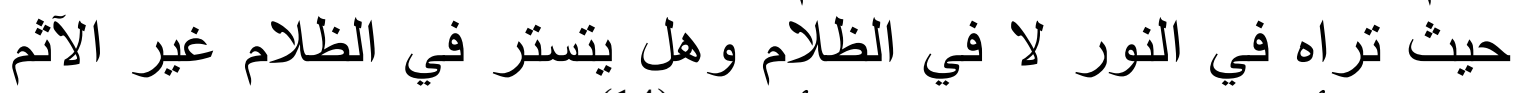

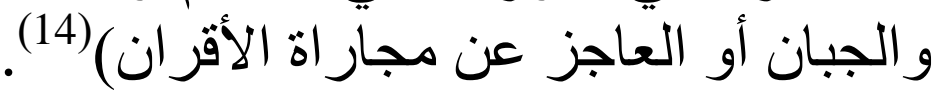

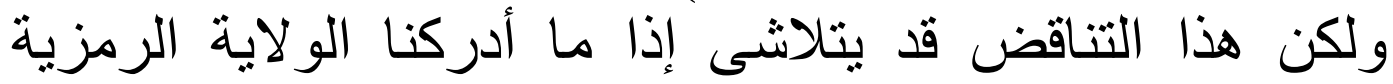

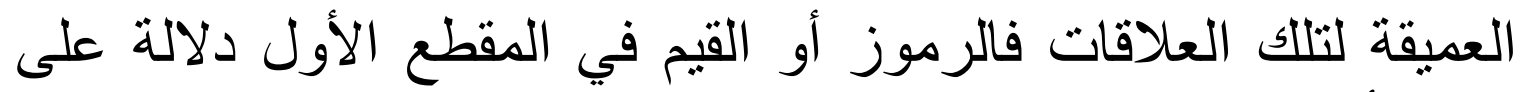
إشارة أشار بها إلى قيم سليمة في الحياة.

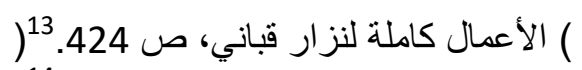

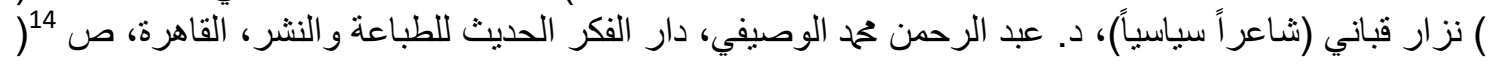
.401 
(فالعمل الفني كما يرى فرويد، تثشكل دوافعه مع دوافع الحل،

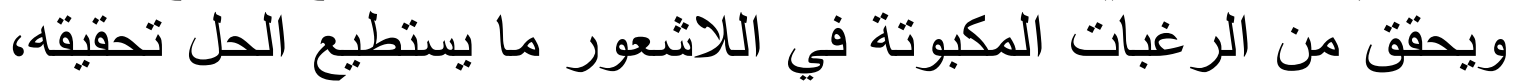
و هو يتخذ في الوقت نفسه من الرموز والصور ما ينفس عن هذه

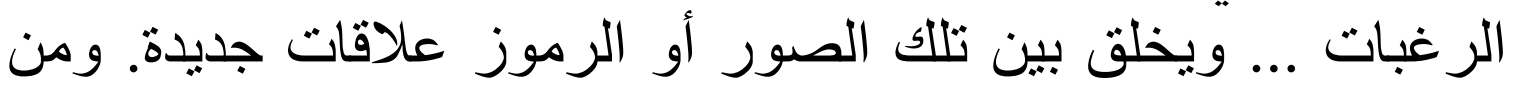

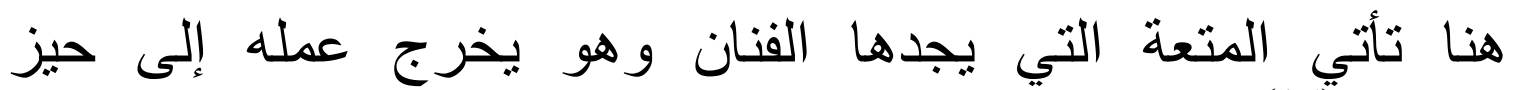

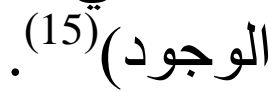

لقد شكل التدخين كما أسلفت سابقاً ظاهرة عند نزار قباني فقد برزت هذه الظاهرة في قصائده وكان توظيف رمز التدخين يتم بطربقة

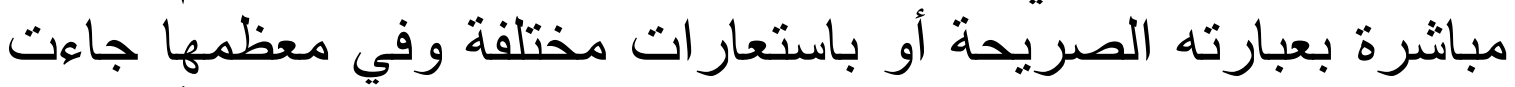

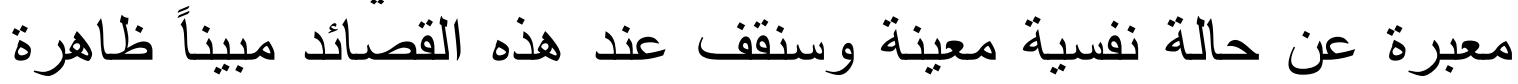

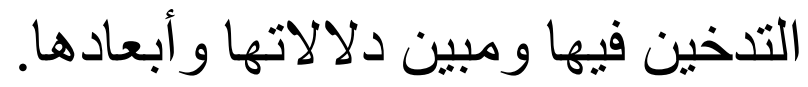
ففي قصيدة (سَاعةَ الصِّفر ) رغم أنه لم يذكر سوى جملة شعرية

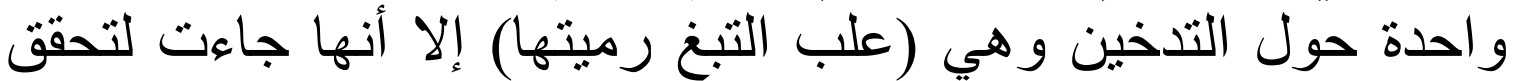

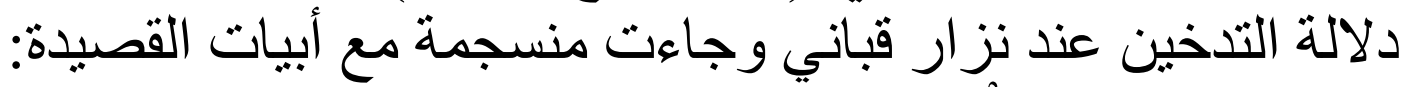

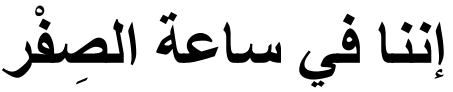
فما تقثر حين أصبحتْ أعصابُنتا فحماً

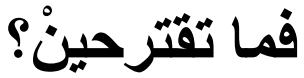

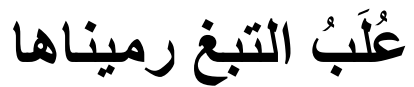

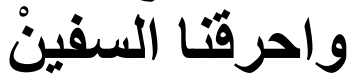
وقثلنا الحبَّ في أعماقينا وهو حس جنين

فساعة الصفر عنوان القصيدة فلو وقفنا عند سبماء العنوان (ساعة الصفر) نجده مجملاً بالدلالات فهو بعني ويعكس حالة الضياع

) مناهج النقد الأدبي الحديث، برنامج التربية المقرر 5344، ص الكمان ) الأعمال الكاملة نز ار قباني، صن 98 
والانتهاء وساعة الصفر تعني النهاية في مستوى من مستوباتها الدلإن. وفي ساعة الصفر بتخلى الإنسان عن أغلى ما يملك و أول شيء تركه نزار وتخلى عنه علبة التبخ (علبة التبخ رميناها) ثم يأتي بعدها مباثرة (واحرقنا السفين) يعني هنا اللاعودة فقيل أن بحرق السفين و تخلى عن علبة التبخ فهو يبني تحليله على الثيء الثمين ولله ارتباط

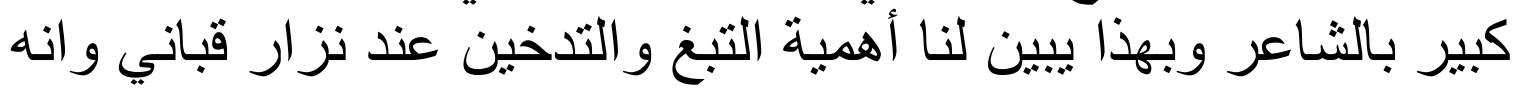
شيء لا بستغنى عنه. و التسلسل في القصيدة مهم، فجاء التخلي عن علب التبغ ثم أحرق السفين ثم بعد ذلك قتل الحب "وقتلنا الحب في أعماقنا" وكان التدخين

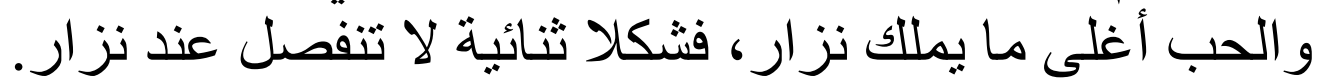
وفي قصيدة "دمُوع شهريَار " ذكر الثَاعر التدخين في قوله له:

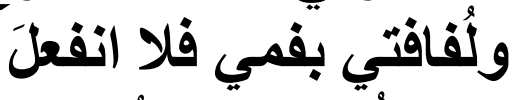

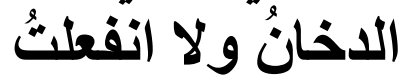

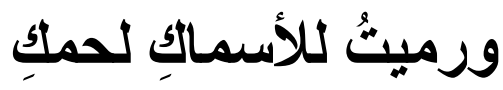

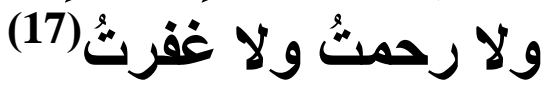

فجاءت الصياغة منسجمة مع فكرة القصيدة المحملة بالموروث التاريخي لقصة شهريار والتي أسقط الثـاعر على نفسه ما تحمله هذه الثخصية التاريخية الأسطورية من دلالات فالاستعارة في بيت الثعر الثر جعلت من الدخان إنسان بنفعل وله مشاعر فالاخخان هو صورة أخرى دئه دئه لثناعر بحس معه وبـه أما في قصيدة (فُستانُ التفتا) فقد ذكر كلمة الدخان في قوله:

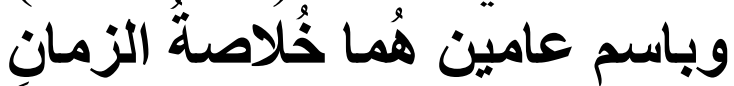

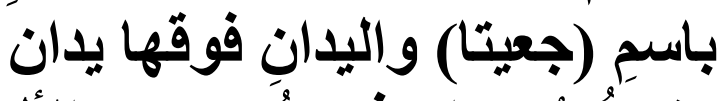

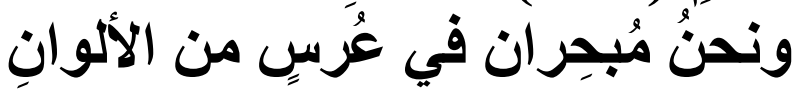
وباسم نادي الصّيد في (جبيل)

) الأعمال الكاملة نزار قباني، ص 106.11 
والتَبْدُ و اللدخان: (18)

فجاء في السباق إلحاح الثاعر على صاحبة فستان التفتا أن تعيد

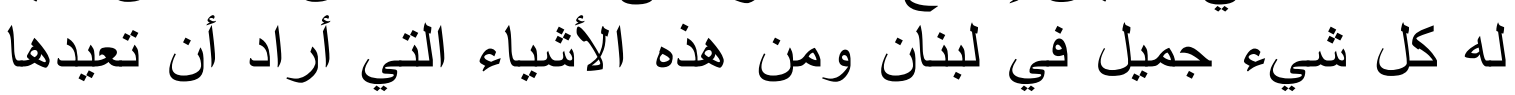
وتشكل أهمية عند الشاعر ولها وقع في القلب (النبذ و الدخان).

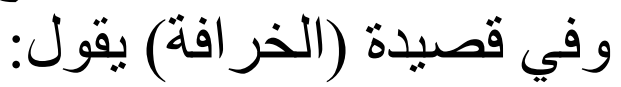

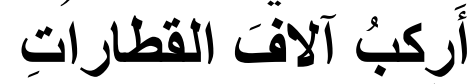

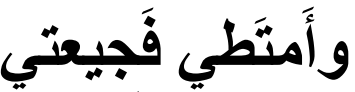

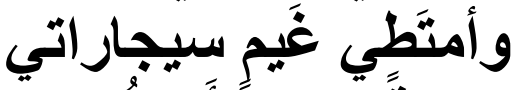

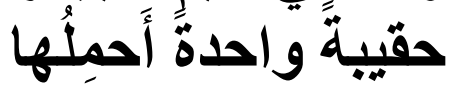
(19)

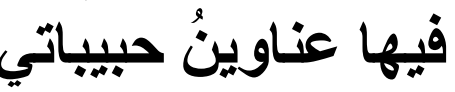
ففي رحلة الهروب ركب آلاف القطارات قطار ات الحزن ويمتطي الغيمة ثم في النهاية بمتطي غيم السيجارة مطية يركبها في رحلة الهروب من الواقع المرير. وفي قصيدة (بانتظار سيدتي) يقول:

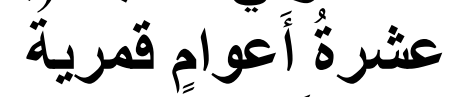

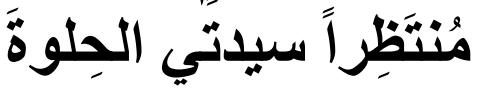

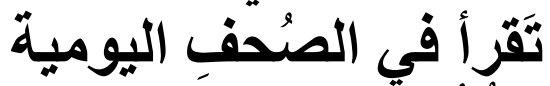

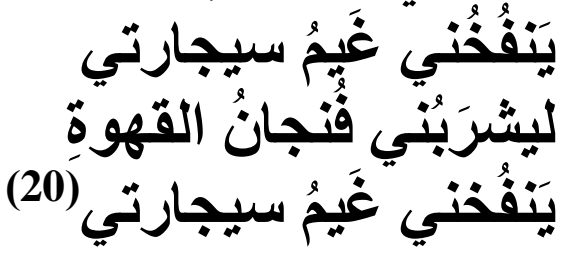

وهنا بعكس الثاعر حالة التوتر و القلق، من لحظات الانتظار،

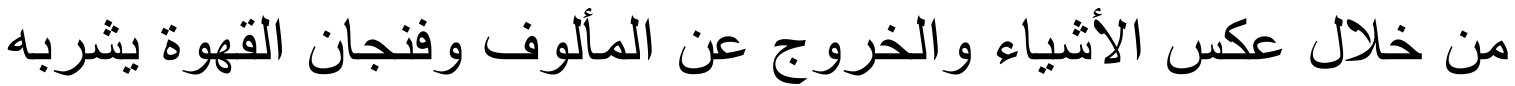
و غيم السيجارة بنفعه، فتأتي هذه العلاقة العكسية لتحقق حالة القلق و الخوف و التوتر وفي نفس القصبدة يقون لون التبغ والورد ككل عامج(21)

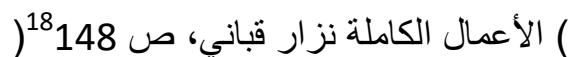

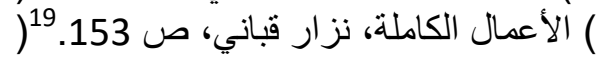

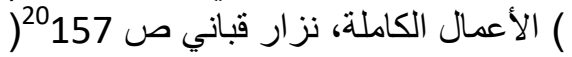

) الأعمال الكاملة، نزار قباني، ص 159. 
فهو يربط حالة التجدد و الحيوية بألوان التبغ و الورد فالتبغ ملازم

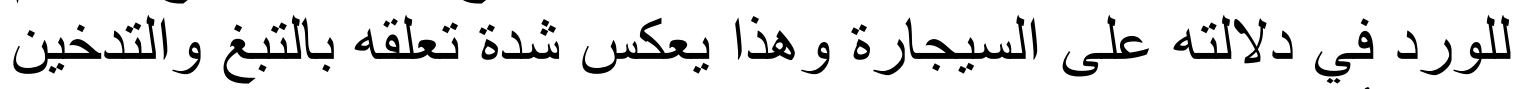

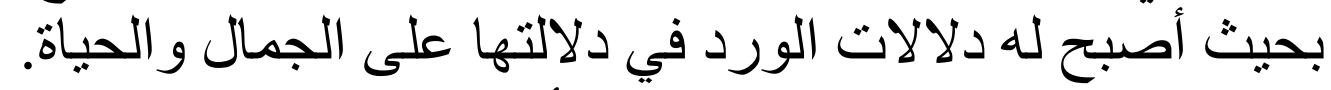

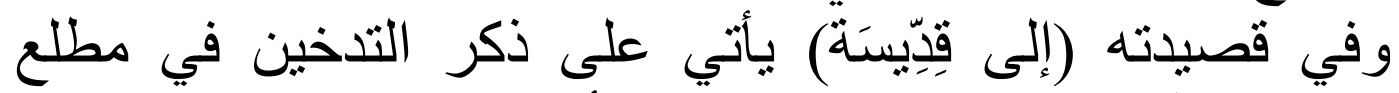

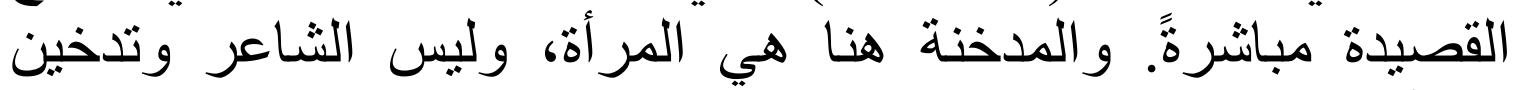

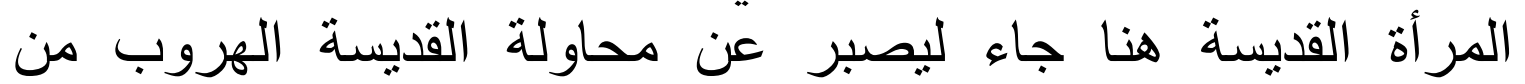
العلاقات الحميمة مع الرجل و التخلي عنها بالتهن التدخين. فالتدخين هنا كأنه

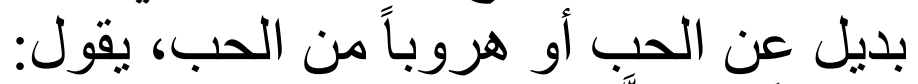

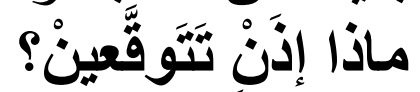

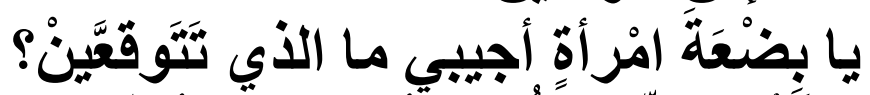

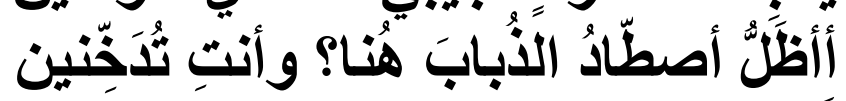

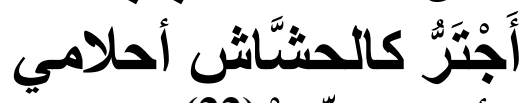

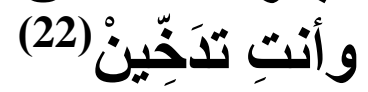
وفي قصيدة "رسائل حب" يقول: وأسمحَح للَّك

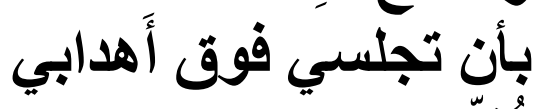
تُغْنَّنْن وتُدخدنّين

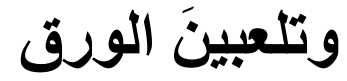
ولا اعترض الاعبن الورق

فهو هنا يسمح لمحبوبته أن تمارس وهي تجلس فوق أهداب

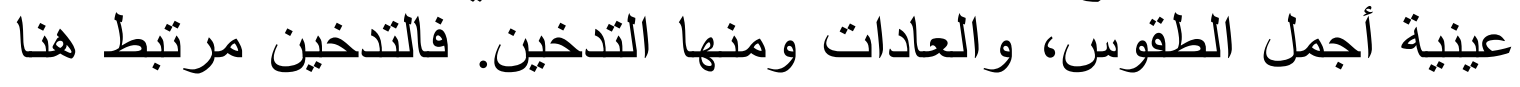
بالغناء و الفرح و السرور.

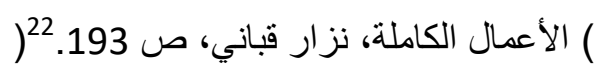

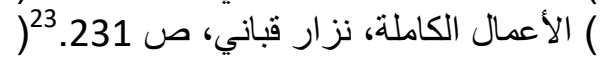




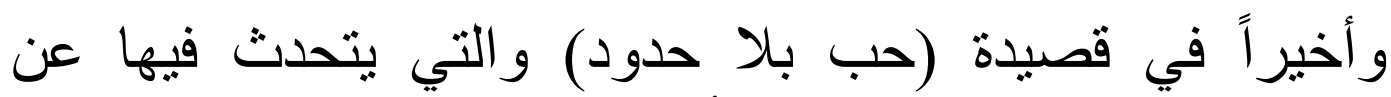
مجزرة قانا ووحثية المعتدي وكيف أتى على كل مل ما هو جميل في قانا

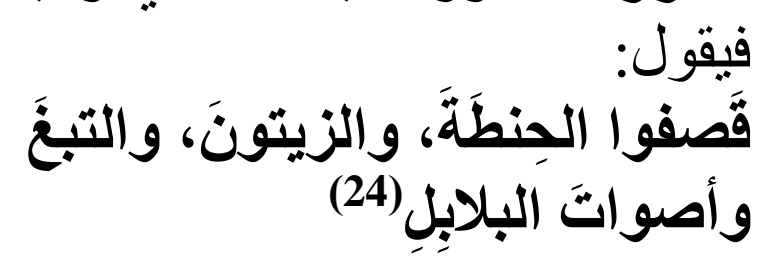

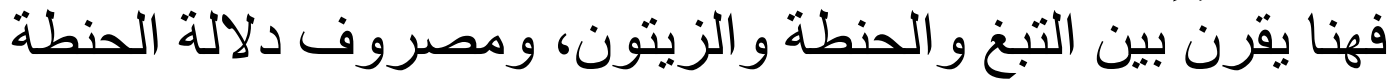

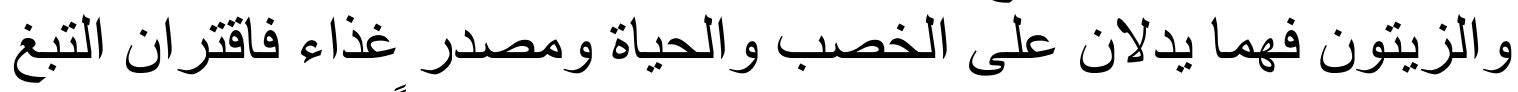

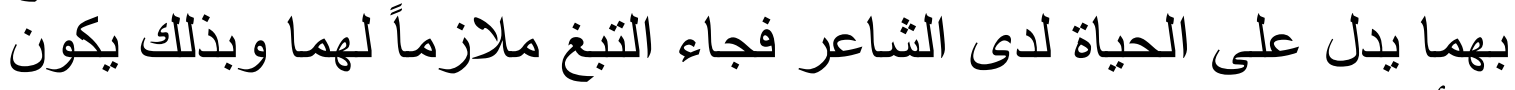

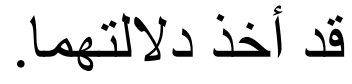

) (الأعمال الكاملة، نزار قباني، ص 536.24 ( ) 


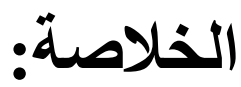

بعد تتبع ظاهرة التدخين في شعر نزار قباني ومحاولة كثف

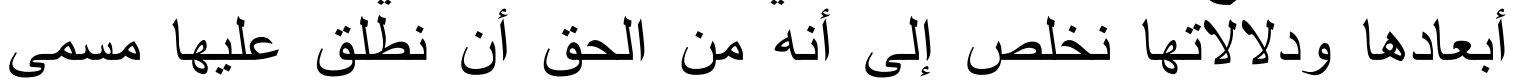

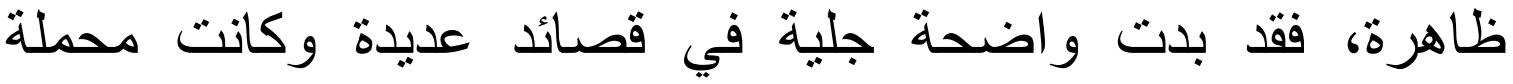

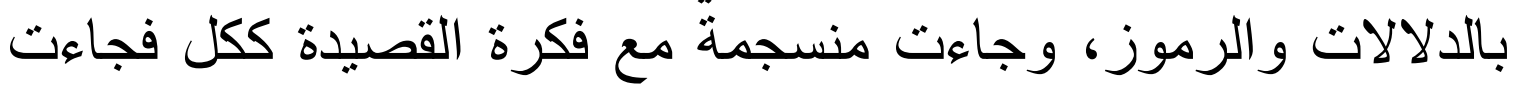

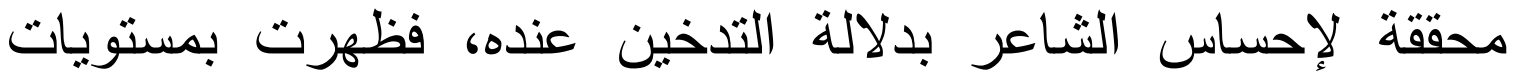

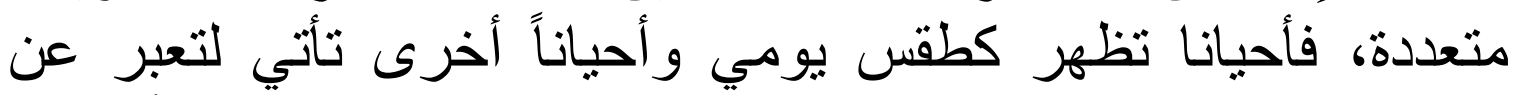

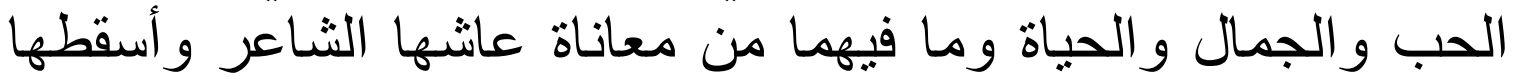

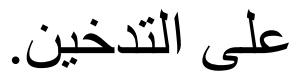




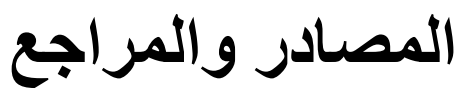

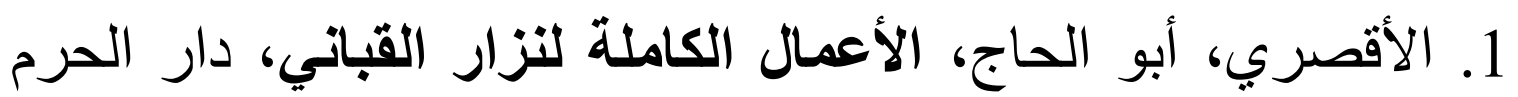

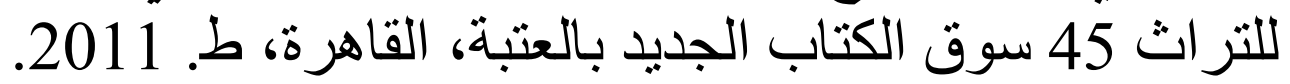

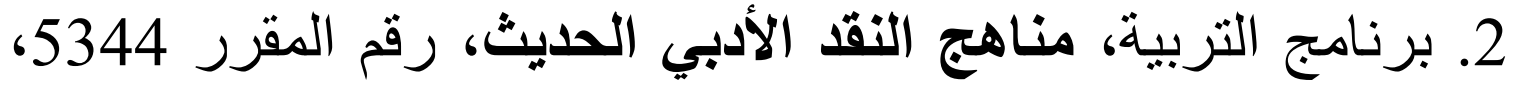
عمان، جامعة القدس المفتوحة. 3. جان، نوبل، التحليل النفسي والأدب، منشورات عويدات، 898، 1996

4. الراية، فايز، علم الدلالة العربي، النظرية والتطبيق، دراسة داصة تاريخية، تأصيلية، نقدية، دار الفية الفكر للطباعة و النشر بدمشق، ط.

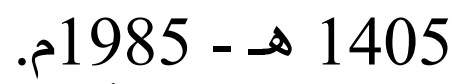
5. سحاب، فكتور، أغنيات نزار قباني، دار الحمر اء للطباعة والنشر،

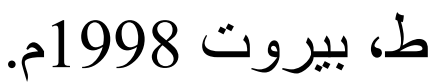
6. شنايدر، أي، التحليل التفسي والفن، ترجمة: يوسف عبد المسيح

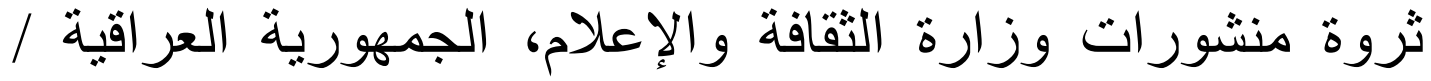
سلسلة الكتب المترجمة (132). 7. كامل، مجدي، نزار شاعر المرأة ... وأحلى ما كتب فئها، فئل، دار

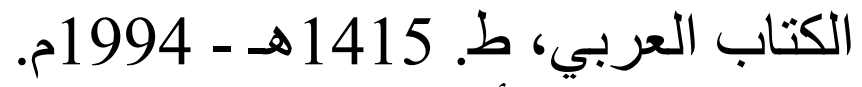
8. المجالي، حمحد أحمد، الشاعران حيدر محمود ونزار قباني. منشور ات أمانة عمان، 2008. 9. المناصرة، عز الدين، جمرة النص الشعري، مقدمات نظرية في

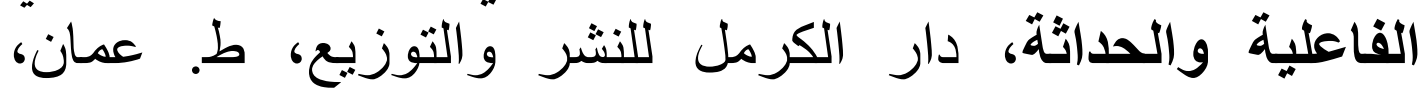
1995م. 10. الوصيفي، عبد الرحمن حجد، نزار قباني شاعراً سياسياً، دار

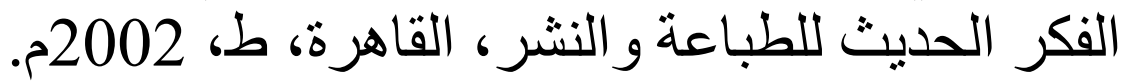

